3 Parkes J, Hyde C, Deeks J, Milne R. Teaching critical appraisal skills in health care settings. In: Cochrane Library. Issue 3. Oxford: Update Software, 2001.

4 Taylor R, Reeves B, Ewings P, Binns S, Keast J, Mears R. A systematic review of the effectiveness of critical appraisal skills training for clinicians. Med Educ 2000;34:120-5.

5 Alguire PC. A review of journal clubs in postgraduate medical education. Jen Intern Med 1998;13:347-53.

6 Smith CA, Ganschow PS, Reilly BM, Evans AT, McNutt RA, Osei A, et al. Teaching residents evidence-based medicine skills: a controlled trial of effectiveness and assessment of durability. J Gen Intern Med 2000;15:710-5.

7 Streiner DL, Norman GR. Health measurement scales. Oxford: University Press, 1995.

8 Lienert GA, Raatz U. Testaufbau und testanalyse. Weinheim: Psychologie Verlagsunion, 1995

9 Cronbach LJ. Coefficient alpha and the internal structure of tests. Psychometrica 1951;16:297-334.

10 Nunnally JC. Psychometric theory. New York: McGraw-Hill, 1978

11 Guyatt G, Rennie D. Users' guides to the medical literature: a manual for evidence-based clinical practice. Chicago: JAMA and Archives Journals,

12 Kunz R, Fritsche L, Neumayer HH. Development of quality assurance criteria for continuing education in evidence-based medicine. $Z$ Arzt Fortbild Qualitatssich 2001;95:371-5.

13 Linzer M, Brown JT, Frazier LM, DeLong ER, Siegel WC. Impact of a medical journal club on house-staff reading habits, knowledge, and critical appraisal skills. A randomized control trial. JAMA 1988;260:2537-41.

14 Khan KS, Awonuga AO, Dwarakanath IS, Taylor R Assessments in evidence-based medicine, Dorksops: loose connection between per evidence-based medicine workshops: loose connection between percep-

15 Kitchens JM, Pfeifer MP. Teaching residents to read the medical literature: a controlled trial of a curriculum in critical appraisal/clinical epidemiology. J Gen Intern Med 1989;4:384-7.

16 Gehlbach SH, Bobula JA, Dickinson JC. Teaching residents to read the medical literature. J Med Educ 1980;55:362-5.

17 Smith CA, Ganschow PS, Reilly BM, Evans AT, McNutt RA, Osei A, et al. Teaching residents evidence-based medicine skills: a co efectivenes rend assessment of durability. $J$ Gen lntern 2000;15:710-5

18 Green ML. Evidence-based medicine training in graduate medical education: past, present and future. J Eval Clin Pract 2000;6:121-38.
19 Cochrane Library. Issue 3. Oxford, Update Software, 2002.

20 American College of Physicians. Best evidence, vol 5. Philadelphia; ACP, 2001

21 Clinical evidence. London: BMJ Publishing, 2001. (Issue 6.)

22 Guyatt GH, Meade MO, Jaeschke RZ, Cook DJ, Haynes RB. Practitioner of evidence based care. Not all clinicians need to appraise evidence from scratch but all need some skills. BMJ 2000;320:954-5.

23 Kirkpatrick DI. Evaluation of training. In: Craig R, Bittel I, ed. Training and development handbook. New York: McGraw-Hill, 1967.

(Accepted 18 October 2002)

\section{Correction}

Developing the role of patients as teachers

An editorial error occurred in the Learning in practice article by Geoff Wykurz and Diana Kelly (12 October, pp 818 21). Some of the references in the list following reference 11 (Blasco et al) should have been reordered and are therefore numbered incorrectly. Reference 20 (Butterworth et al) should have been reference 12, and reference 16 (Plymale et al) should have been reference 13 . The original references $12,13,14,15,17,18$, and 19 become 14, 15, 16, 17, 18, 19, and 20 , respectively.

As a consequence, two amendments need to be made to the text. On page 819 , in the section on evaluation of patients' involvement, reference 12 should be the new reference 13 (Plymale et al) and the sentence in question should read: "Some patients felt empowered by their experience. ${ }^{13} 18$ " On page 819 , in the section on recruitment, remuneration, and status of patients, reference 13 should be the new reference 12 (Butterworth et al): "One article was coauthored by the chairperson of a carers' organisation, which implies a close partnership. ${ }^{12}$ " We apologise for these errors.

\title{
Computer madness
}

Those damned computers will drive me to an early retirement. I'm fed up with having to resuscitate fatally flawed programs instead of caring for patients. Nothing irritates me more than having to reboot repeatedly in front of a waiting room full of unsympathetic onlookers. My hardware man and my software man don't answer their pagers. "Try pressing that button," suggests a well meaning patient.

Back in the examining room, Mrs N is pouring out her troubles when she notices me suddenly tuning her out because the computer screen has gone blank. "Just hold on to that tearfulness, Mrs N, I'll be with you in a moment." The day will come when I'll put in a claim for worker's disability compensation citing "computer generated stress disorder."

Since 1998, Israeli health maintenance organisations require that all patient charts be computerised. Patients carry plastic cards with magnetic strips that they present at the clinic in lieu of payment. My secretary passes the card, and, after a cacophony of computer talk, the screen informs us that Big Brother authorises the visit. A patient chart cannot be opened until permission to treat is given. Doctors are not paid unless a patient's plastic card is properly passed. "We've been off line for the past half hour," she informs me. The cleaning lady, who is looking on, suggests, "Try pressing that button."

We all learnt about patient centred and disease centred medical care. My approach can best be described as computer centred. This begins every morning the moment I arrive at the clinic. I need to start 30 minutes before any patients appear if I'm to have a chance. Firstly, I check that all three computers are still working and haven't been sabotaged by a midnight power outage. Next, I check if the program backing up the patient charts kicked in properly. Often it hasn't, which is why we have a backup for the backup. Finally, I need to connect to my insurance carriers via the modem. If everything is working as it should, my modem receives all the day's laboratory, $x$ ray, and other ancillary test results. Did I say computers were all bad?

But sometimes, Big Brother loses track of what he has already sent me, and I receive results of throat cultures from four months ago. I'm up to lab result number 84 , and the program cannot be shut off. The only way to halt this parade is to reboot again.

My partner feels much like me. Whenever we have a few moments to sit down together over coffee, instead of talking about the day's interesting patient, we talk about what went wrong with our electronic gadgetry. We commiserate with each other, and no one else seems to understand. To make matters worse, for every computer problem that pops up there's a well meaning nudnik nearby with a quick fire solution to offer or, at the very least, has a brother in law who does. I usually follow the cleaning lady's advice when she says, "Try pressing that button."

Joseph Rothenberg family physician, Jerusalem, Israel

We welcome articles up to 600 words on topics such as A memorable patient, A paper that changed my practice, My most unfortunate mistake, or any other piece conveying instruction, pathos, or humour. If possible the article should be supplied on a disk. Permission is needed from the patient or a relative if an identifiable patient is referred to. We also welcome contributions for "Endpieces," consisting of quotations of up to 80 words (but most are considerably shorter) from any source, ancient or modern, which have appealed to the reader. 